\title{
Some key issues for the next Clinton administration
}

\author{
Russ Hoyle
}

Despite a relentless conservative Congressional assault, the White House has managed to engineer a truly astonishing political turnaround, comparable to Truman's comeback in 1948 after the 1946 Democratic midterm debacle. "I can't believe this happened," says one Washington environmentalist who vividly recalls the despair and shock after the 1994 midterm elections. "This was political jujitsu."

Along the way, the White House managed to score some significant victories. The Clinton Environmental Protection Agency (Washington, DC) took the wind out of Republican sails by approving premarket registration of genetically engineered pesticidal plant products developed by Ciba-Geigy (Greensboro, NC), Mycogen Plant Sciences (San Diego, $\mathrm{CA}$ ), and Monsanto (St. Louis, $\mathrm{MO}$ ). And last summer, the administration rammed through a new pesticide bill that did away with the infamous Delaney Clause and paved the way for more biotechnology products.

Though new product approvals were proof positive of effective regulatory machinery, the White House underscored its success by announcing last winter that the 25 top industry, government, and environmental leaders who made up the President's Council on Sustainable Development, cochaired by Dow Chemical's David Buzzelli and Jonathan Lash of the World Resources Institute, had concluded that the existing federal regulatory system was sound, if in need of fine tuning.

The White House also renewed its emphasis on the development of innovative technologies for international markets. This was fortuitous, new genetically engineered US products such as Monsanto's Roundup Ready soybeans immediately ran into a regulatory wall in Europe, effectively blocked by the European Commission (EC, Brussels).

The issue of harmonizing international regulatory standards among major US trading partners has fast become the most pressing of a handful of items on the biotechnology agenda for a second Clinton administration. Observers of the agricultural biotechnology industry in particular agree that Washington has its work cut out for it. Other issues Washington regulators and policymakers will have to grapple with include recasting the Superfund law, managing resistance to new transgenic plants, and patent reform.

Herewith, a brief rundown on the key policy issues that are likely to shape the agenda for the biotechnology industry in the next four years.

\section{Trade harmonization}

There is little question that the future of the industry depends in large part upon the successful negotiation of harmonized standards for safety, efficacy, and environmental impact between the US and its major trading partners.

Although Monsanto's soybeans were eventually approved by the EC, in large part because the product was not sold in seed form, questions linger about the EC approval process and consumer-acceptance issues sparked by the controversy.

Agbiotechnology officials would like to see harmonized standards based on accepted science, rather than on ethical or economic considerations, that build on existing regulatory regimes. Like the US regulatory system, such a system would be based on scrutiny of products, not the manufacturing process. Some greens see the trade controversy as leverage for bringing US regulation of genetically engineered products into line with stricter European standards. Certain observers believe such international standards might be negotiated through the Codex Alimentarius, an international standard-setting body for trade in processed foods. Others question whether the Codex is up to making judgments about a subject as complex as genetic engineering.

\section{The biosafety protocol}

There appears to be a growing consensus within the biotechnology industry that the failure of the United States to ratify the 1992 Biodiversity Treaty has tied its hands in ongoing talks about the so-called biosafety protocol that would establish broad guidelines for how countries and international corporations deal with biological products. The Clinton administration has moved from opposing such a protocol, for fear of draconian international regulation, to accepting a biosafety protocol that is science-based and within the established framework of risk assessment and management that has proven adequate in the US, Europe, and elsewhere.

Controversy over the protocol has, of course, mounted as the first significant spate of US agbiotechnology products, including genetically engineered biopesticides and herbicides, is now poised for international marketing. In late July, US industry officials attended the Open-Ended Ad Hoc Working Group of Experts on Biosafety, which met in Aarhus, Denmark. It was the first time the biotechnology industry established an independent presence in a venue established by the treaty signatories.

The Ad Hoc group agreed that the basis of the proposed protocol should be draft propos- als submitted by treaty signatories. The US, at this point, will have to content itself with submitting positions on such elements of the protocol as prior notification of trade and liability and compensation issues. Critics worry that, without US input into an acceptable protocol, US companies will be called upon to subsidize development in countries that cannot afford to do so themselves.

\section{Supertund reform}

As in 1994, when Superfund reauthorization was humiliatingly defeated, the Clinton administration seems determined to send a message to the $\$ 180$ billion-a-year environmental services industry that the development of innovative, less expensive bioremediation technologies are on the administration's front burner again. The Superfund reform effort, in which a second Clinton administration is prepared to earmark some $\$ 2$ billion for cleanup of the 30,000-odd Superfund cleanup sites, will provide for somewhat looser and more fiexible cleanup standards, encourage new technologies that now make up some $20 \%$ of the Superfund arsenal and improve both liability and site-appropriate public health standards. This initiative represents an area in which the Clinton administration could well engineer dramatic policy changes.

\section{Monopoly, patents, FDA reform}

Other issues will also occupy administration policymakers in coming years. Regulators, the $\mathrm{EPA}$, and agbiotechnology companies are working on perhaps the greatest threat to new transgenic plants, the development of pest resistance and attempts to come up with resistance management techniques. As biotechnology start-up companies continue to be gobbled up by corporate giants, questions of monopoly control of research and development, as well as of world trade, will inevitably arise. The US patent system is still a costly mess, and its reform could only encourage innovation. On the drug side, the US Food and Drug Administration (Rockville, MD) streamlining that began in the first term will undoubtedly continue. And the new bioethics commission could have a salutary effect on anticipating future problems, such as regulating transgenic animals, most immediately fish.

Remarkably, through bouts of bungling, brilliance, and plain dumb luck, a second Clinton-Gore administration is poised to take the biotechnology industry to the next level if its vision remains steady and its political will strong. 